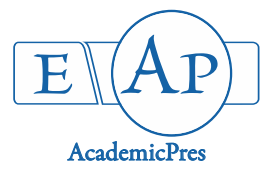

\title{
Effect of Methanolic Fruit Extract of Piper guineense on Serum Biochemical Parameters and Histomorphology of the Liver and Kidney of Male Albino Rats (Rattus norvegicus)
}

\author{
Chidozie N. OKOYE ${ }^{1}$, Izuchukwu S. OCHIOGU ${ }^{1}$, Onyinyechukwu A. \\ AGINA $^{2 *}$, Ukamaka U. EZE ${ }^{3}$, Nnenna O. NWACHUKWU ${ }^{1}$, Ikechukwu J. \\ $\mathrm{UDEANI}^{2}$, Ifeanyi G. EKE ${ }^{4}$, Susan O. DAN-JUMBO ${ }^{1}$
}

\author{
${ }^{1}$ University of Nigeria, Faculty of Veterinary Medicine, Department of Veterinary Obstetrics and Reproductive Diseases, Nsukka, Nigeria \\ ${ }^{2}$ University of Nigeria, Faculty of Veterinary Medicine, Department of Veterinary Pathology and Microbiology, Nsukka, \\ Nigeria; onyinye.noel@unn.edu.ng ( ${ }^{*}$ corresponding author) \\ ${ }^{3}$ University of Nigeria, Faculty of Veterinary Medicine, Department of Veterinary Medicine, Nsukka, Nigeria \\ ${ }^{4}$ University of Nigeria, Faculty of Veterinary Medicine, Department of Physiology and Pharmacology, Nsukka, Nigeria
}

\begin{abstract}
Piper guineense fruit is known for its nutritive and medicinal values. This study evaluated the biochemical effect of the methanol fruit extract of $P$. guineense on male albino rats. A total of thirty-eight (38) adult male Sprague-Dawley albino rats were used for the study. Eighteen of the male rats were used for the acute toxicity study, while twenty (20) male rats were randomly assigned into four groups (A, B, C and D) of 5 rats each, for the sub-acute toxicity study. Groups B, C and D were the treatment groups, while group A was the control group and received only distilled water $(10 \mathrm{mg} / \mathrm{ml})$. Groups B, C and D received $10 \mathrm{mg} / \mathrm{kg}, 200 \mathrm{mg} / \mathrm{kg}$ and $400 \mathrm{mg} / \mathrm{kg}$ body weight of the fruit extract respectively. Administration of the $100 \mathrm{mg} / \mathrm{kg}$, $200 \mathrm{mg} / \mathrm{kg}$ and $400 \mathrm{mg} / \mathrm{kg}$ of methanol fruit extract of P. guineense led to a significant $(\mathrm{P}<0.05)$ increase in the serum ALT and AP on day 7 of the experiment. Throughout the experimental period, $200 \mathrm{mg} / \mathrm{kg}$ of the extract caused a significant $(\mathrm{P}<$ $0.05)$ increase in serum total proteins and globulin. Group D rats had significantly $(\mathrm{P}<0.05)$ lower serum total cholesterol on day 28 of the experiment. The $100 \mathrm{mg} / \mathrm{kg}$ of the extract caused a significant increase in serum urea and creatinine on day 21 of the experiment. Oral administration of methanol fruit extract of $P$. guineense caused mild hepatocellular injury, hyperproteinemia, hyperglobulinemia, hypocholesterolemia, and mild renal toxicity.
\end{abstract}

Keywords: Piper guineense, mild hepatocellular injury, mild renal toxicity, Rattus norvegicus

\section{Introduction}

Phytomedicine is becoming increasingly popular with little regard to the possible toxic potentials (Ekere et al., 2013). Though phytomedicine contributed to the development of important and widely used pharmaceutical agents today (Balick and Cox, 1997), it is still worrisome that little attention is given to the possible side effects, especially with long-term phytomedical therapeutic regimens (Omoja et al., 2015). Piper guineense, which is native to tropical West Africa, belongs to the family Piperaceae or Sapotaceae (Macmillan, 1984; Iwu, 1993). It is used as an aromatic spice in various dishes to which it imparts "pungency" (Udoh et al., 1996). The essential oils from the plant are used for perfumery and soap making. The plant leaves and fruit are used for various phytomedical purposes. The fruit is used folklorically as an aphrodisiac (Mbongue et al., 2005), while different preparations of the leaves and fruit are used ethnomedically for female reproductive health issues (Udoh et al., 1999; Mbongue et al., 2005; Ekanem et al., 2010). The plant fruit is used for weight control because it is free of fat and cholesterol (Duvauchelle, 2011), and also as an antibiotic (Mbongue et al., 2005), as an analgesic (Mbongue et al., 2005), and as a febrifuge (Ekanem $e t$ al., 2010). Phytochemical analysis of the plant fruit reveals the presences of alkaloids, cyanide, flavonoids, glycosides, phelobatinins, polyphenols, saponins, steroids etc. (Udoh, 1999; Uhegbu et al., 2011). Some of these phytochemicals are toxic and may be injurious to tissues and organs of the body. It is therefore needful to investigate the effects of oral administration of graded doses of methanol fruit extract of $P$. guineense on the body. 
Clinical evaluation of organ-specific serum enzyme activities is very important in the diagnosis of diseases and pathologic conditions, toxicological assessments and monitoring of pharmacologic response to different therapeutic interventions (Yakubu et al., 2005; Gowda et al., 2010). Evaluation of the organ-specific serum enzyme activity is imperative, as it reveals the functional status of key organs that are involved in the maintenance of the integrity of the internal milieu of the body (Palanivel $e t$ al., 2008). Furthermore, such biochemical lesions become apparent even before obvious histopathological lesion are observed (Wei et al., 2001) and could as such serve as early warning markers especially for organs that have great functional reserve like the liver.

This study thus investigated the effects of oral administration of graded doses of methanol fruit extract of Piper guineense on the serum activities/levels of alanine aminotransferase (ALT), alkaline phosphatase (ALP), aspartate aminotransferase (AST), total proteins, albumin, globulin, cholesterol, blood urea nitrogen (BUN) and creatinine, as well as histomorphology of the liver and kidney of male albino rats.

\section{Materials and Methods}

\section{Experimental animals}

A total of 38 adult male Sprague-Dawley albino rats weighing between $240 \pm 20 \mathrm{~g}$ were used for the study. The rats were procured from the Laboratory Animal House of the Department of Pathology and Microbiology, Faculty of Veterinary Medicine, University of Nigeria, Nsukka. The rats were kept in groups in stainless steel cages in the Experimental Animal House of the Department of Veterinary Obstetrics and Reproductive Diseases, Faculty of Veterinary Medicine, University of Nigeria, Nsukka, under standard conditions (ambient temperature: $22-28{ }^{\circ} \mathrm{C}$; approximately 12 hours natural day light; humidity: $50-60 \%)$. They were allowed two weeks to acclimatize; commercial pelleted feed (Vital', GCOML, Nigeria) containing $14.5 \%$ crude protein and $2,500 \mathrm{Kcal} / \mathrm{kg}$ metabolizable energy and water were provided ad libitum.

\section{Extraction of plantmaterial}

Fresh fruits of Piper guineense were procured from Orba, Enugu State, Nigeria. The fruits were authenticated by a plant taxonomist. The fruits were air-dried under room temperature and then pulverized and weighed. The plant fruit crude extract was obtained by cold maceration method using $80 \%$ methanol with regular intermittent agitation. The crude extract was filtered using Whatman size-1 filter paper and the resultant filtrate was concentrated to obtain a dry crude extract. The crude extract was weighed to determine the percentage yield and was preserved at $4{ }^{\circ} \mathrm{C}$ throughout the duration of the study.

\section{Experimentaldesign \\ Acute toxicity}

The determination of $\mathrm{LD}_{50}$ of the plant fruit extract was as described by Lorke (1983) using 18 of the rats.

\section{Sub-chronic study}

Twenty of the male albino rats were randomly assigned into four groups designated $\mathrm{A}, \mathrm{B}, \mathrm{C}$ and $\mathrm{D}$, of 5 rats each.
Groups B, C and D were the treatment groups, while group A was the untreated control group that received $10 \mathrm{mg} / \mathrm{ml}$ of distilled water for the duration of the study. Group B received $100 \mathrm{mg} / \mathrm{kg}$, group C received $200 \mathrm{mg} / \mathrm{kg}$, while group D received $400 \mathrm{mg} / \mathrm{kg}$ body weight (b.w.) of the plant fruit extract respectively. The rats were dosed between 9 to $10 \mathrm{am}$, for 28 days every other day, with the aid of an orogastric gavage.

\section{Serum sample collection and analysis}

Blood samples were taken at weekly intervals between 8 to $9 \mathrm{am}$. Blood samples were collected from the retrobulbar plexus via the median canthus of the eye of the rats. Serum samples were harvested from the blood samples by centrifugation at $10,000 \mathrm{~g}$ for 10 minutes. All the serum biochemistry determinations were carried out immediately after separation of the serum from blood clot.

\section{Serum biochemistry determination}

The serum biochemistry determinations were carried out using commercial test kits, Quimica Clinica Aplicada (QCA) test kits (QCA, Spain) and a digital colorimeter (Lab-tech, India). The serum alanine aminotransferase (ALT) was determined by the Reitman-Frankel method (Reitman and Frankel, 1957). The serum alkaline phosphatase (AP) activity was determined by the phenolphthalein monophosphate method (Babson et al., 1966), while the total bilirubin was determined by the Jendrassik-Grof method (Doumas et al., 1973). The total serum proteins were determined by the direct Biuret method (Lubran, 1978), while the serum albumin was determined by the Bromocresol green method (Doumas et al., 1971). The serum urea was determined by the modified Berthelot-Searcy method (Fawcett and Scott, 1960), while the serum creatinine was determined by the modified Jaffe method (Blass et al., 1974). The serum cholesterol was determined by the CHOD-POD method (Allain et al., 1974).

\section{Tissue collection}

At the end of the study, kidney and liver tissues were harvested from the euthanized rats.

\section{Histological preparation}

The liver and kidney tissue samples were promptly fixed in Bouins fluid and further histological preparations were done as described by Igwebuike and Eze (2010), and stained by hematoxylin and eosin for light microscopy. Photomicrographs were captured using a Moticam digital camera (Motic China Group Co., Ltd., Xiamen, China).

\section{Ethical approval}

The housing, handling and welfare of the rats used for the study were done humanely in accordance with the Ethics and Regulation Guiding the Use of Research Animals as approved by the University of Nigeria, Nsukka.

\section{Data analysis}

Data generated were subjected to repeated measure one way analysis of variance (ANOVA), and variant means were separated by the least significant difference (LSD) method. Significance was accepted at $\mathrm{P}<0.05$. Final results were presented as means \pm standard error $(\mathrm{SE})$. 


\section{Results}

\section{Acute toxicity test}

The percentage yield of the plant fruit extract was $2.84 \%$. Acute toxicity test showed that the plant seed methanol extract was well tolerated at the maximum dose of $5,000 \mathrm{mg} / \mathrm{kg}$ body weight.

\section{Sub-acute toxicity study \\ Serum biochemistry tests}

On day 7 of treatment, groups B, C and D had significantly $(\mathrm{P}<0.05)$ higher serum ALT activity when compared to the group A (Table 1$)$. No significant $(\mathrm{P}>0.05)$ difference was recorded for the serum ALT activity across the groups on day 14 of treatment, but group $\mathrm{D}$ had significantly $(\mathrm{P}<0.05)$ lower ALT activity when compared to the control on day 21 of treatment (Table 1$)$. However, on day 28 a significantly $(\mathrm{P}<$ 0.05 ) higher serum ALT activity was recorded for groups $B$ and $\mathrm{C}$ only when compared to control groups (Table 1). The serum ALP activity of the treatment groups was significantly ( $\mathrm{P}$ $<0.05$ ) higher than that of the control group on day 7 (Table 2). No significant $(P>0.05)$ difference was recorded between the treatment groups and the control group after 14 days, but on day 21 the serum ALP activity of group C rats was significantly $(\mathrm{P}<0.05)$ lower than that of the control group and the other treatment groups (Table 2). By day 28 there was no significant $(\mathrm{P}>0.05)$ variation in serum ALP activity across the groups (Table 2).

The serum total proteins levels of group $\mathrm{C}$ rats were significantly $(\mathrm{P}<0.05)$ higher than that of the control and group $\mathrm{D}$ rats throughout the 28 days of treatment, while that of group $B$ rats were significantly $(\mathrm{P}<0.05)$ higher than that of the control and group $\mathrm{D}$ rats only on days 7 and 21 of treatment (Table 3).

On day 7 of treatment, groups B and D rats had significantly $(\mathrm{P}<0.05)$ lower serum albumin level when compared to the control group (Table 4). A significantly $(\mathrm{P}<$ 0.05 ) higher serum albumin level was recorded for group $D$ rats when compared to the control group on day 21 (Table 4).
There was no significant $(\mathrm{P}>0.05)$ difference in the serum albumin level of the treatment groups when compared to the control group on days 14 and 28 of treatment (Table 4). The serum globulin level of groups $\mathrm{C}$ and $\mathrm{D}$ only were significantly $(\mathrm{P}<0.05)$ higher than that of the control group on days 7 and 14 of treatment, while on day 21 the serum globulin level of groups $\mathrm{B}$ and $\mathrm{C}$ only were significantly $(\mathrm{P}<0.05)$ higher than that of the control group (Table 5). On day 28 of treatment group $\mathrm{C}$ alone had a significantly $(\mathrm{P}<0.05)$ higher serum globulin level compared to the control group (Table 5 ).

No significant $(P<0.05)$ difference was recorded for the serum cholesterol level across the groups on days 7 and 14 of treatment (Table 6). On day 21 of treatment, only group B had a significantly $(\mathrm{P}<0.05)$ higher serum cholesterol level compared to that of the control group, while on day 28 of treatment only group $\mathrm{D}$ had a significantly $(\mathrm{P}<0.05)$ lower serum cholesterol level compared to that of the control group (Table 6).

The serum urea level of groups $\mathrm{B}$ and $\mathrm{C}$ rats was significantly $(\mathrm{P}<0.05)$ lower than that of the control group on day 7 of treatment (Table 7). On days 14 and 28 there was no significant $(\mathrm{P}>0.05)$ difference in the serum urea level between the treatment groups and the control group (Table 7). However, on day 21, the serum urea level of the treatment groups was significantly $(\mathrm{P}<0.05)$ higher than that of the control group A (Table 7 ).

The serum creatinine level of groups $B$ and D rats was significantly $(\mathrm{P}<0.05)$ lower than that of the control group on day 7 of treatment (Table 8). On day 14, there was no significant $(\mathrm{P}>0.05)$ difference in the serum urea level between the treatment groups and the control group (Table 8). However, on day 21 , the serum creatinine level of only group B was significantly $(\mathrm{P}<0.05)$ higher than that of the control group $\mathrm{A}$, while on day 28 of treatment group $\mathrm{C}$ had a significantly $(\mathrm{P}<0.05)$ lower serum creatinine level compared to the control (Table 8$)$.

Sections of the liver and kidney of the rats that received graded doses of methanol fruit extract of Piper guineense for 28 days orally showed no obvious histopathologic lesions (Figs. 1

Table 1. Mean serum ALT (IU/l) activities (means \pm standard error) of rat groups administered methanol fruit extract of Piper guineense for 28 days

\begin{tabular}{|c|c|c|c|c|}
\hline Days & Group A (control) & Group B (100 mg/kg b.w.) & Group C (200 mg/kg b.w.) & Group D (400 mg/kg b.w.) \\
\hline 7 & $27.41 \pm 3.51^{\mathrm{a}}$ & $35.55 \pm 1.28^{\mathrm{bc}}$ & $33.12 \pm 0.99^{b}$ & $36.36 \pm 0.81^{\mathrm{c}}$ \\
\hline 14 & $32.37 \pm 2.40^{\mathrm{a}}$ & $34.01 \pm 3.51^{\mathrm{a}}$ & $32.37 \pm 0.82^{\mathrm{a}}$ & $29.07 \pm 2.56^{\mathrm{a}}$ \\
\hline 21 & $29.06 \pm 0.50^{\mathrm{a}}$ & $27.02 \pm 1.89^{\mathrm{a}}$ & $24.17 \pm 5.68^{\mathrm{ab}}$ & $17.23 \pm 3.95^{\mathrm{b}}$ \\
\hline 28 & $40.09 \pm 1.76^{\mathrm{a}}$ & $48.63 \pm 1.71^{\mathrm{b}}$ & $44.42 \pm 2.08^{c}$ & $40.10 \pm 2.52^{\mathrm{ac}}$ \\
\hline
\end{tabular}

${ }^{\mathrm{a}-\mathrm{c}}$ Different superscripts across a row indicates significant differences between the means $(\mathrm{P}<0.05)$

Table 2. Mean serum ALP (IU/l) activities (means \pm standard error) of rat groups administered methanol fruit extract of Piper guineense for 28 days

\begin{tabular}{|c|c|c|c|c|}
\hline Days & Group A (control) & Group B (100 mg/kg b.w.) & Group C (200 mg/kg b.w.) & Group D (400 mg/kg b.w.) \\
\hline 7 & $98.63 \pm 1.93^{\mathrm{a}}$ & $129.00 \pm 5.54^{b}$ & $111.00 \pm 5.67^{c}$ & $139.35 \pm 3.00^{\mathrm{d}}$ \\
\hline 14 & $121.20 \pm 5.46^{\mathrm{ab}}$ & $121.20 \pm 8.21^{\mathrm{ab}}$ & $128.80 \pm 3.32^{b}$ & $110.40 \pm 7.52^{\mathrm{a}}$ \\
\hline 21 & $135.72 \pm 31.51^{\mathrm{ac}}$ & $164.57 \pm 34.56^{a}$ & $91.72 \pm 5.91^{b}$ & $108.57 \pm 3.50^{c}$ \\
\hline 28 & $131.21 \pm 0.16^{\mathrm{a}}$ & $131.72 \pm 0.20^{\mathrm{a}}$ & $131.48 \pm 0.30^{\mathrm{a}}$ & $131.72 \pm 0.21^{\mathrm{a}}$ \\
\hline
\end{tabular}

Table 3. Mean serum total protein $(\mathrm{g} / \mathrm{dl})$ levels (means \pm standard error) of rat groups administered methanol fruit extract of Piper guineense for 28 days

\begin{tabular}{|c|c|c|c|c|}
\hline Days & Group A (control) & Group B (100 mg/kg b.w.) & Group C (200 mg/kg b.w.) & Group D (400 mg/kg b.w.) \\
\hline 7 & $6.73 \pm 0.14^{a}$ & $5.72 \pm 0.36^{b}$ & $7.37 \pm 0.09^{c}$ & $6.60 \pm 0.17^{a}$ \\
\hline 14 & $6.07 \pm 0.16^{\mathrm{a}}$ & $5.95 \pm 0.20^{\mathrm{a}}$ & $6.47 \pm 0.16^{b}$ & $6.27 \pm 0.20^{\mathrm{ab}}$ \\
\hline 21 & $6.22 \pm 0.36^{a}$ & $7.44 \pm 0.49^{b}$ & $7.28 \pm 0.54^{b}$ & $6.50 \pm 0.98^{\mathrm{ab}}$ \\
\hline 28 & $7.25 \pm 0.21^{\mathrm{ab}}$ & $7.39 \pm 0.17^{b}$ & $8.25 \pm 0.51^{c}$ & $6.86 \pm 0.30^{\mathrm{a}}$ \\
\hline
\end{tabular}


Table 4. Mean serum albumin $(\mathrm{g} / \mathrm{dl})$ level (means \pm standard error) of rat groups administered methanol fruit extract of Piper guineense for 28 days

\begin{tabular}{|c|c|c|c|c|}
\hline Days & Group A (control) & Group B (100 mg/kg b.w.) & Group C (200 mg/kg b.w.) & Group D (400 mg/kg b.w.) \\
\hline 7 & $4.22 \pm 0.13^{a}$ & $3.43 \pm 0.35^{b c}$ & $3.99 \pm 0.23^{\mathrm{ab}}$ & $3.32 \pm 0.12^{c}$ \\
\hline 14 & $3.41 \pm 0.14^{\mathrm{ab}}$ & $3.41 \pm 0.00^{\mathrm{b}}$ & $3.30 \pm 0.09^{\mathrm{a}}$ & $3.49 \pm 0.14^{\mathrm{ab}}$ \\
\hline 21 & $2.00 \pm 0.21^{\mathrm{a}}$ & $2.19 \pm 0.21^{\mathrm{ab}}$ & $2.00 \pm 0.12^{\mathrm{a}}$ & $2.64 \pm 0.27^{b}$ \\
\hline 28 & $3.53 \pm 0.11^{\mathrm{a}}$ & $3.53 \pm 0.13^{\mathrm{a}}$ & $3.48 \pm 0.25^{a}$ & $3.20 \pm 0.32^{\mathrm{a}}$ \\
\hline
\end{tabular}

${ }^{a-c}$ Different superscripts across a row indicates significant differences between the means $(\mathrm{P}<0.05)$

Table 5. Mean serum globulin ( $\mathrm{g} / \mathrm{dl}$ ) levels (means \pm standard error) of rat groups administered methanol fruit extract of Piper guineense for 28 days

\begin{tabular}{|c|c|c|c|c|}
\hline Days & Group A (control) & Group B (100 mg/kg b.w.) & Group C (200 mg/kg b.w.) & Group D (400 mg/kg b.w.) \\
\hline 7 & $2.51 \pm 0.09^{\mathrm{a}}$ & $2.29 \pm 0.16^{\mathrm{a}}$ & $3.37 \pm 0.17^{\mathrm{b}}$ & $3.27 \pm 0.18^{b}$ \\
\hline 14 & $2.66 \pm 0.22^{\mathrm{a}}$ & $2.54 \pm 0.20^{\mathrm{a}}$ & $3.16 \pm 0.23^{b}$ & $2.77 \pm 0.17^{b}$ \\
\hline 21 & $4.22 \pm 0.30^{\mathrm{a}}$ & $5.25 \pm 0.33^{b}$ & $5.28 \pm 0.49^{b}$ & $3.85 \pm 0.49^{\mathrm{a}}$ \\
\hline 28 & $3.72 \pm 0.16^{\mathrm{a}}$ & $3.86 \pm 0.14^{\mathrm{a}}$ & $4.77 \pm 0.53^{b}$ & $3.67 \pm 0.46^{\mathrm{a}}$ \\
\hline
\end{tabular}

Table 6. Mean serum cholesterol ( $\mathrm{mg} / \mathrm{dl}$ ) levels (means \pm standard error) of rat groups administered methanol fruit extract of Piper guineense for 28

\begin{tabular}{|c|c|c|c|c|}
\hline Days & Group A (control) & Group B (100 mg/kg b.w.) & Group C (200 mg/kg b.w.) & Group D (400 mg/kg b.w.) \\
\hline 7 & $90.91 \pm 9.96^{\mathrm{a}}$ & $105.45 \pm 10.60^{a}$ & $94.55 \pm 3.64^{\mathrm{a}}$ & $94.55 \pm 8.91^{\mathrm{a}}$ \\
\hline 14 & $101.82 \pm 9.27^{\mathrm{a}}$ & $87.27 \pm 13.36^{\mathrm{a}}$ & $87.27 \pm 6.80^{\mathrm{a}}$ & $94.55 \pm 6.80^{\mathrm{a}}$ \\
\hline 21 & $88.42 \pm 5.37^{\mathrm{a}}$ & $98.95 \pm 4.21^{\mathrm{b}}$ & $87.32 \pm 3.19^{\mathrm{a}}$ & $92.63 \pm 7.73^{\mathrm{ab}}$ \\
\hline 28 & $65.93 \pm 8.02^{\mathrm{a}}$ & $63.89 \pm 27.49^{\mathrm{ab}}$ & $60.20 \pm 12.11^{\mathrm{ab}}$ & $44.56 \pm 9.85^{b}$ \\
\hline
\end{tabular}

${ }^{a-b}$ Different superscripts across a row indicates significant differences between the means $(\mathrm{P}<0.05)$

Table 7. Mean serum urea ( $\mathrm{g} / \mathrm{dl}$ ) levels (means \pm standard error) of rat groups administered methanol fruit extract of Piper guineense for 28 days

\begin{tabular}{ccccc}
\hline Days & Group A (control) & Group B $(100 \mathrm{mg} / \mathrm{kg}$ b.w. $)$ & Group C $(200 \mathrm{mg} / \mathrm{kg}$ b.w. $)$ & Group D (400 mg/kg b.w.) \\
\hline 7 & $29.33 \pm 1.63^{\mathrm{a}}$ & $22.67 \pm 2.67^{\mathrm{b}}$ & $21.33 \pm 2.50^{\mathrm{b}}$ & $26.67 \pm 2.98^{\mathrm{ab}}$ \\
14 & $18.91 \pm 2.12^{\mathrm{a}}$ & $18.91 \pm 2.11^{\mathrm{a}}$ & $18.18 \pm 1.63^{\mathrm{a}}$ & $16.73 \pm 2.72^{\mathrm{a}}$ \\
21 & $17.72 \pm 2.10^{\mathrm{a}}$ & $26.29 \pm 2.77^{\mathrm{b}}$ & $23.43 \pm 3.55^{\mathrm{b}}$ & $22.86 \pm 1.28^{\mathrm{b}}$ \\
28 & $15.71 \pm 4.98^{\mathrm{a}}$ & $10.06 \pm 2.08^{\mathrm{ab}}$ & $11.89 \pm 1.37^{\mathrm{a}}$ & $9.84 \pm 0.57^{\mathrm{a}}$ \\
\hline
\end{tabular}

${ }^{a-b}$ Different superscripts across a row indicates significant differences between the means $(\mathrm{P}<0.05)$

Table 8. Mean serum creatinine ( $\mathrm{g} / \mathrm{dl})$ levels (means \pm standard error) of rat groups administered methanol fruit extract of Piper guineense for 28 days

\begin{tabular}{|c|c|c|c|c|}
\hline Days & Group A (control) & Group B (100 mg/kg b.w.) & Group C (200 mg/kg b.w.) & Group D ( $400 \mathrm{mg} / \mathrm{kg}$ b.w.) \\
\hline 7 & $0.80 \pm 0.12^{\mathrm{a}}$ & $0.50 \pm 0.13^{b}$ & $0.70 \pm 0.18^{\mathrm{ab}}$ & $0.54 \pm 0.11^{\mathrm{b}}$ \\
\hline 14 & $0.95 \pm 0.15^{\mathrm{a}}$ & $0.67 \pm 0.17^{\mathrm{a}}$ & $0.93 \pm 0.24^{\mathrm{a}}$ & $0.85 \pm 0.16^{\mathrm{a}}$ \\
\hline 21 & $1.32 \pm 0.21^{\mathrm{a}}$ & $1.80 \pm 0.20^{\mathrm{b}}$ & $1.52 \pm 0.22^{\mathrm{ab}}$ & $1.32 \pm 0.21^{\mathrm{a}}$ \\
\hline 28 & $0.60 \pm 0.00^{\mathrm{a}}$ & $0.69 \pm 0.09^{\mathrm{a}}$ & $0.52 \pm 0.00^{\mathrm{b}}$ & $0.58 \pm 0.05^{\mathrm{a}}$ \\
\hline
\end{tabular}

${ }^{\mathrm{a}-\mathrm{b}}$ Different superscripts across a row indicates significant differences between the means $(\mathrm{P}<0.05)$

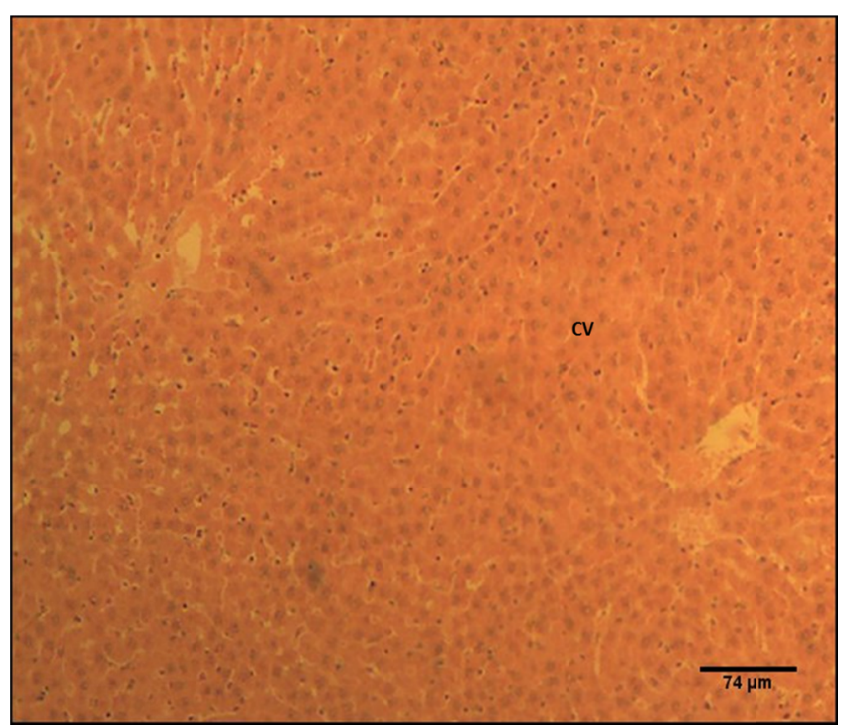

Fig. 1. Histological appearance of liver of rat given $200 \mathrm{mg} / \mathrm{kg}$ body weight of methanol fruit extract of Piper guineense orally for 28 days, showing no obvious lesions. Note the central vein $(\mathrm{CV})$, and cords of hepatocytes. $\mathrm{H} \& \mathrm{E} \times 100$

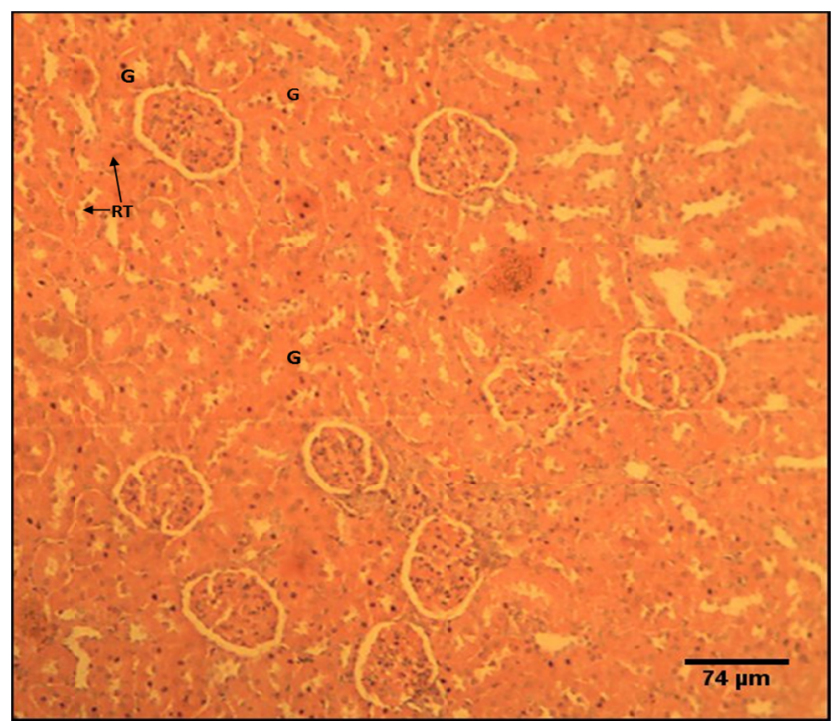

Fig. 2. Histological appearance of kidney of rat given 200 $\mathrm{mg} / \mathrm{kg}$ body weight of methanol fruit extract of Piper guineense orally for 28 days, showing no obvious lesions. Note the glomeruli (G) amidst renal tubules (RT). H \& E × 100 
and 2). The histomorphology of sections of the liver and kidney of all the rat groups that received graded doses of methanol fruit extract of Piper guineense showed normal cords of hepatocytes that converged on the central vein and renal tubules interspersed with glomeruli respectively (Figs. 1 and 2).

\section{Discussion}

The results of the acute toxicity test showed that the rats tolerated up to $5,000 \mathrm{mg} / \mathrm{kg}$ body weight dose of the extract without mortality or obvious signs of toxicity and thus suggests that the methanol fruit extract of $P$. guineense is "unlikely to present acute hazard in normal use" (WHO, 2001).

Administration of all doses of methanol fruit extract of $P$. guineense as used in this study, led to increases in serum ALT and AP on day 7. This could be attributed to mild hepatocellular injury, as insult to the hepatocytes can cause leakage of liver enzymes into peripheral circulation (Ajibade $e t$ al., 2008; Stockham and Scott, 2008).

A non-significant change in their serum activities on day 28 could be attributed to the fact that the liver, as a site of biotransformation, has inactivated the toxic compound in the extract into a less toxic metabolite. This is the body's way of responding and overcoming stress induced by toxic substances (Hodgson, 2004; Uthman et al., 2013). This finding is in contrast with data of Adefegha and Oboh (2012) and Nwaichi and Igbinobaro (2012), who reported non-significant difference and significant reduction in the liver enzymes respectively following oral administration of $P$. guineense. The increase in serum total proteins could be attributed to high protein content of $P$. guineense (Echo et al., 2012; Uhegbu et al., 2015). Hyperglobulinemia as recorded in this study shows that the $P$. guineense fruit extract may be helpful in improving the immune status of an animal. The decreased serum cholesterol concentration show that the fruit extract may possess hypocholesterolemic potentials (Adefegha and Oboh, 2012; Uhegbu et al., 2015). This further reveals that the fruit extract could have beneficial effects of reducing cardiovascular complications in certain metabolic diseases such as diabetes (Nwaichi and Igbinobaro, 2012; Ekoh et al., 2014). The increase in serum urea and creatinine levels was observed only on day 21 of the study, and it could be attributed to mild toxic effect of the methanolic fruit extract on the kidneys. This is not in agreement with Uhegbu et al. (2015) who reported that the $P$. guineense seed extract may be used to improve renal function in rats.

The absence of any obvious histopathologic lesions in the sections of the liver and kidney of the rats treated with graded doses of methanol fruit extract of $P$. guineense in this study may be due to the short duration of treatment which lasted only 28 days. More so, administration of xenobiotic often produces enzymatic and biochemical lesions before the appearance of histological lesions (Haschek et al., 2009), thus the time of onset of histopathologic lesion needed is more. Additionally observation of histopathologic lesion would warrant treating with a dose of the extract that would overwhelm the functional reserves of the liver and kidney.

\section{Conclusions}

It can be concluded that the oral administration of methanolic seed extract of $P$. guineense caused mild hepatotocellular injury, hyperproteinemia, hyperglobulinemia, hypocholesterolemia and mild renal toxicity and longer time is needed to investigate the long-term effects.

\section{Acknowledgements}

This study was funded by the personal resources of the authors. No grant was made available for the study.

\section{References}

Adefegha SA, Oboh G (2012). Effect of diets supplemented with Ethiopian pepper [Xylopia aethiopica (Dun.) A. Rich (Annonceae)] and Ashanti pepper [Piper guineense Schumach. et Thonn (Piperaceae)] on some biochemical parameters in normal rats. Asian Pacific Journal of Tropical Biomedicine 2(2):559-567.

Ajibade TO, Olayemi FO, Arowolo ROA (2012). The haematological and biochemical effects of methanol extract of the seeds of Moringa oleifera in rats.Journal of Medicinal Plants and Research 6(4):615-621.

Allain CC, Poon LS, Chan CS, Richmond W, Fu PU (1974). Enzymatic determination of total cholesterol. Clinical Chemistry 20:470-475.

Babson AL, Greeley SJ, Coleman CM, Philips GE (1966). Phenolphthalein monophosphate as a substrate for serum alkaline phosphatase. Clinical Chemistry 12:482-490.

Blass KG, Thieber RJ, Lam LK (1974). A study of the mechanism of the Jaffe reaction. Journal of Clinical Biochemistry 12:336-343

Colville J (2002). Blood Chemistry. In: Hendrix CM (Ed). Laboratory Procedures for Veterinary Technicians. 4th ed. Mosby, St Louis pp 75-103.

Doumas BT, Perry BW, Sasse EA, Straumfjord Jr. JV (1973). Standardization in bilirubin assays: Evaluation of selection methods and stability of bilirubin solutions. Clinical Chemistry 19:984-993.

Doumas BT, Watson W, Biggs HG (1971). Albumin standards and the measurement of serum albumin with bromocresol green. Clinical Chimica Acta 31:87-96.

Duvauchelle J (2011). Okra nutrition information. Retrived 2014 August 12 from http://www.livestrong.com/article/371351-okranutrition-information $/ \mathrm{html}$.

Echo IA, Osuagwu AN, Agbor RB, Okpako EC, Ekanem BE (2012). Phytochemical composition of Aframomum melegueta and Piper guineense seeds. World Journal of Applied Environmental Chemistry 2(1):17-21.

Ekanem AP, Udoh FV, Oku EE (2010). Effects of ethanol extract of Piper guineense seeds (Schum and Thonn) on the conception of mice (Mus Muscular). African Journal of Pharmaceutical Pharmacology 4:362-267.

Ekere SO, Okoye CN, Udoumoh AF (2013). Fertility enhancing effects of methanolic leaf extract of Dracaenea arborea in albino rats (Rattusnorvegicus). Czech Journal of Animal Science 58:520-524. 
Fawcett JK, Scott JE (1960). A rapid and precise method for the determination of urea. Journal of Clinical Pathology 13:156-159.

Gowda S, Desai PB, Kulkarni SS, Hull VV, Math AK, Vernekar SN (2010). Markers of renal function tests. North American Journal of Medical Sciences 2:170-173.

Haschek WM, Rousseaux CG, Wallig, MA (2009). Clinical pathology In: Fundamental of Toxicologic Pathology. Elsevier Inc. pp 43-65.

Hodgson E (2004). A textbook of modern toxicology, 3rd Ed. John Wiley and Sons Inc. New Jersey.

Ihedioha JI, Okafor C, Ihedioha TE (2004). The haematological profileof the Sprague-Dawley outbred albino rat in Nsukka, Nigeria. Animal Research International 1:125-132.

Iwu MM (1993). Handbook of African medicinal plants. CRC Press.

Lorke D (1983). A new approach to practical acute toxicity testing, archives of toxicology Archives of Toxicology 54(4):275-287.

Lubran MM (1978). The measurement of total serum proteins by the Biuret method. Annals of Clinical Laboratory Science 8:106-110.

Macmillan HF (1984). A handbook for tropical planting and gardening. Macmillan Scientific Publishers, London.

Mbongue FGY, Kamtchouing P, Essame OJL, Yewah PM, Dimo T, Lontsi D (2005). Effect of the extract of dry fruits of Piper guineense on the reproductive function of adult male rats. Indian Journal of Pharmacology 37:30-32.

Nwaichi EO, Igbinobaro O (2012). Effects of some selected spices on some biochemical profile of wistar albino rats. American Journal of Environmental Engineering 2(1):8-11.

Nwozo SO, Ajagbe AA, Oyinloye BE (2012). Hepatoprotective effect of Piper guineense aqueous extract against ethanol-induced toxicity in male rats. Journal of Experimental and Integrative Medicine 2:71-76.

Omoja VU, Ekere SO, Okoye CN, Mbegbu EC (2015). Leucopoetic and testestorone levels of rats administered sub-chronic methanolic leaf extract of Dracenea arborea. Comparative Clinical Pathology 24:527-532.
Palanivel MG, Rajkapoor B, Kumar RS, Einstein JW, Kumar EP, Kumar MR, Kavitha K, Kumar MP, Jayakar B (2008). Hepatoprotective and antioxidant effect of Pisonia aculeate $\mathrm{L}$. against CCL4-induced hepatic damage in rats. Science Pharmacology 76:203-215.

Reitman S, Frankel S (1957). A colorimetric method for determination of serum glutamic oxaloacetic and glutamic pyruvic transaminase. American Journal of Clinical Pathology 28:56-62.

Stockham SL, Scott MA (2008). Fundamentals of veterinary clinical pathology, 2nd ed. Blackwell Publishing Iowa, USA.

Udoh FV (1999). Uterine muscle reactivity to repeated administration and phytochemistry of the leaf and seed extracts of Piper guineense. Phytotherapy Research 13:55-58.

Udoh FV, Akpan JO, Ufaruna N (1996). Effect of extract of leaf and seed of Piper guineense on some smooth muscle activity in rat, guinea-pig and rabbit. Phytotherapy Research 10:596-599.

Udoh FV, Lot TY, Braide VB (1999). Effect of extract of seed and leaf of Piper guineense on skeletal muscle activity in rat and frog. Phytotherapy Research 13:106-110.

Uhegbu FO, Iweala EEJ, Kanu I (2011). Studies on the chemical and antinutritional content of some Nigerian spices. International Journal of Nutrition and Metabolism 3:72-76.

Uhegbu, FO, Imo C, Ugbogu AE (2015). Some biochemical changes in serum of female albino rats administered aqueous extract of Piper guineense Schumach seeds. International Journal of Biochemistry Research and Review 8(1):1-7.

Wei L, Hjerpe A, Brisma BH, Sevensson O (2001). Effect of load or articular cartilage matrix and development of guinea pig osteoarthritis. Osteoarthritis and Cartilage 9:447-453.

WHO (2001) The World Health Organisation (WHO) recommended classification of pesticides by hazards and guidelines for classification. 2000-2001, WHO, Geneva.

Yakubu MT, Adebayo OJ, Egwim EC (2005). Increased liver ALP and aminotransferase activities following administration of ethanolic extract of Khaya senegalensi stem bark to rats. Biokemistri 17:27-32. 